\title{
COMPOSITION OF TERMITES IN THREE DIFFERENT SOIL TYPES ACROSS OIL PALM AGROECOSYSTEM REGIONS IN RIAU (Indonesia) AND JOHOR (Peninsular Malaysia)
}

\author{
ANDI SAPUTRA*; DZULHELMI MUHAMMAD NASIR ${ }^{*, * *}$; NUR-ATIQAH JALALUDIN*; MADIHAH HALIM*; \\ ASRAF BAKRI*; MOHAMMAD FARIS MOHAMMAD ESA*; IZFA RIZA HAZMI* and FASZLY RAHIM ${ }^{\ddagger}$
}

\begin{abstract}
Termites are perceived as decomposers and as pests in an ecosystem. A study on the species composition of termites in different soil types (i.e. clay, sand and peat) in oil palm plantations was conducted between 6 April 2015 and 10 December 2015 in nine selected localities in Johor (Malaysia) and Riau (Indonesia). Sampling of termites was conducted using belt transects of $100 \mathrm{~m}$ in length and $4 \mathrm{~m}$ in width in the oil palm plantation. A total of three replicates for each soil types were done from the nine transects for each location. A total of 41 species from five subfamilies (i.e. Coptotermitinae, Rhinotermitinae, Termitinae, Macrotermitinae and Nasutitemitinae) and two families (i.e. Rhinotermitidae and Termitidae) of termite species were successfully sampled and recorded. Sand soil (81 colonies: 12 species; four subfamilies; two families) recorded the highest colonies, followed by peat soil (62 colonies: 12 species; five subfamilies; two families), and clay soil (47 colonies consisting; nine species, four subfamilies and two families). There was a significant difference ( $\left.\chi^{2}=618886, d f=328, p<0.005\right)$ between soil types and termite species composition that were found in the oil palm plantation. This study identified that the diversity and abundance of termites differed between soil types in different oil palm plantations.
\end{abstract}

Keywords: composition of termites, oil palm agroecosystem.

Date received: 22 January 2018; Sent for revision: 28 February 2018; Received in final form: 18 July 2018; Accepted: 21 August 2018

\section{INTRODUCTION}

Termites from the order Blattodea are social insects that live in colonies and can be found in abundance in tropical soil ecosystems (Eggleton et al., 1996).

\footnotetext{
Centre for Insect Systematics,

School of Environmental and Natural Resource Sciences,

Faculty of Sciences and Technology,

Universiti Kebangsaan Malaysia,

43600 Bangi, Selangor, Malaysia.

E-mail: andi.saputra.riau@gmail.com

** Present address

Malaysian Palm Oil Board,

6 Persiaran Institusi, Bandar Baru Bangi,

43000 Kajang, Selangor, Malaysia

‡ Centre of PERMATA Insan,

Islamic Science University of Malaysia,

Complex PERMATA Insan, Bandar Bahru Nilai,

71800 Nilai, Negeri Sembilan, Malaysia.
}

They are very important in soil ecosystems, playing significant role in decomposing organic matters (Duc et al., 2016), providing ecosystem services (i.e. soil formation and aeration) (Lavelle et al., 2006) and promoting biodiversity by creating suitable condition for other biotas in an ecosystem (Korb, 2007). They are highly dependent on the use of woods as food and nesting site (Duc et al., 2016). Some termite species have been known as pests (Poovoli and Rajmohana, 2016) and cause serious damages and losses to agriculture, forest, urban structures, earthen dams and underground electrical cables (Azam et al., 2015). Out of 2650 species (280 genera and seven families) throughout the world (Kambhampati and Eggleton, 2000), at least 325 species (51 genera, 10 subfamilies and four families) of termites have been identified as pests in agriculture in South-east Asia (Tho, 1992). 
From the past - often for centuries, the natural forests have been extensively converted to agriculture particularly oil palm plantations for South-east Asia countries (Foster et al., 2011). To date, an estimated $20 \%$ or 2590000 ha and $28.65 \%$ or 2493176 ha of land masses which consist of different soil types (i.e. sand, clay, peat) have been converted to oil palm in Peninsular Malaysia and Indonesia (Riau Province, Sumatra), respectively (Direktorat Jenderal Perkebunan, 2016; Gunasro et al., 2013; Kamalrudin et al., 2014; Wendy and William, 2015). The conversion of these land mass may have affected the various soil invertebrates' community especially termites. The changes in their microhabitat may have contributed to the differences in their diversity, abundance and composition (e.g. Davies et al., 2003; Dibog et al., 1999). Therefore, the present study aimed to compare the species composition and abundance of termites in three different soil types, i.e. clay, sand and peat in an oil palm plantation.

\section{MATERIALS AND METHODS}

This study was conducted between 6 April 2015 and 10 December 2015 in four localities in Peninsular Malaysia and five localities in Indonesia (Table 1). These localities were selected according to the distinction of land use change, management practices, macrohabitat and other factors such as proximity to the river basin, highlands, and soil types.

In this study, the transect protocol was adopted and modified from Jones and Eggleton (2002) as there were differences in width range of 2 to $4 \mathrm{~m}$. The modification of the transect protocol were to: (1) accommodate the windrows and planted rows (Saputra et al., 2016b; Faszly et al., 2011), (2) uniformise the sampling quadrats $(1 \mathrm{~m} \times 4 \mathrm{~m})$ of $1 \mathrm{~m}$ apart on the belt transects (Saputra et al., 2017), (3) take into account the load of dead wood and piles of dry leaves (fronds heap and stack line) on the sites. This transect protocol modification has been previously proposed and tested (e.g. Faszly, 2008; Faszly et al., 2011; Saputra, 2017).

In determining the types of soil, we referred to the soil type layout map generated by the oil palm plantation management. According to our observation, clay type soil is very compact and sticky. Clay soil is naturally high in nutrients, holds moisture well and keeps plants hydrated. We observed that drainage water movement was slow because clay has smaller air particles. Sand soil is in opposite appearance with larger particle size and it has lots of air spaces. Therefore, water movement was quick (drainage observation) (Hardjowigeno, 1989; Islami and Utomo, 1995). However, it does not hold nutrients as well as clay. Lastly, for peat soils, they are classified as histosols with high in organic mater content which have sedentarily accumulated and have at leat $30 \%$ (dry mass) organic matter at depth of at least $45 \mathrm{~cm}$ on undrained land and $30 \mathrm{~cm}$ deep on drained land (Dika, 2010).

For each quadrat along the transect, samples were collected by two individuals within a maximum time of $30 \mathrm{~min}$. The samples were then sorted within $12 \mathrm{hr}$ to ensure the termites were alive before being preserved in the vials containing $70 \%$ alcohol. Species identification was made from references by Syaukani (2004), Thapa (1981) and Tho (1992).

For statistical analyses, a two-way cluster analysis was performed to determine the similarity of each species at different locations. This analysis was also expected to determine the possibilities of each species that may appear on other part of the transects. The non-multidimensional scaling (NMDS) was then performed to determine the termite community structures and to find the most influential environmental factors that may influence them whether non-normal or arbitrary, discontinuous or questionable scales (McCune et al., 2002). This ordination technique aims to compare and determine the differences in termites' communities in each of the soil types. Moreover, a Chi-square was used to determine the significant difference in species composition among taxa at different sites. The two-way cluster analyses and NMDS were performed using PC Ord 6 (MjM Software, Oregon, 2001) while Chi-square was performed using Minitab 17 (Minitab Inc, 2016).

\section{RESULTS}

A total of 41 species representing five subfamilies namely Coptotermitinae, Rhinotermitinae, Termitinae, Macrotermitinae and Nasutitemitinae and two families (Rhinotermitidae and Termitidae) were successfully collected and recorded from nine selected localities (171 population) (Table 2). From the number of individuals collected, family Termitidae recorded 33 species and 12 genera from three subfamilies i.e. Termitinae, Macrotermitinae, Nasutitermitinae $(73.38 \%)$, while Rhinotermitidae recorded nine species and three genera from Coptotermitinae and Rhinotermitinae (26.76\%) (Table 2). The species collected presents the termite species found in the oil palm agroecosystem in Riau (Indonesia) and Johor (Peninsular Malaysia).

Termite species and composition varied greatly among soil types. The sand soil recorded the highest colonies (81 hits: 12 species; four subfamilies; two families), followed by peat soil (62 hits: 12 species; five subfamilies; two families), and clay soil (47 hits: nine species, four subfamilies and two families). Based on the two-way cluster analysis and dendogram, nine species groups and five locality 
TABLE 1. TRANSECT SAMPLING LOCATIONS AT OIL PALM AGROECOSYSTEM REGIONS IN RIAU (Indonesia) AND JOHOR (Peninsular Malaysia)

\begin{tabular}{|c|c|c|c|c|c|}
\hline $\begin{array}{l}\text { Location } \\
\text { code }\end{array}$ & Name of location & Regency/region & $\begin{array}{c}\text { Type of agroecosystem } \\
\text { \& type of soil }\end{array}$ & GPS & Date \\
\hline \multirow[t]{2}{*}{ IdBCB } & Indonesia Batang Cenaku & Indragiri Hulu & Small plantation \& & S. $00^{\circ} 36^{\prime} 571$ & \\
\hline & Belilas & & clay soil ${ }^{1}$ & E. $102^{\circ} 33^{\prime} 592$ & 6 March 2015 \\
\hline \multirow[t]{2}{*}{ MyFNT } & Malaysia Felda & Johor & Company plantation \& & N. $020^{\circ} 22^{\prime} 145$ & \\
\hline & Nitar Timur & & clay soil ${ }^{1}$ & E. $103^{\circ} 45^{\prime} 472$ & 8 December 2015 \\
\hline \multirow[t]{2}{*}{ MyFKT } & Malaysia Felda & Johor & Company plantation \& & N. $02^{\circ} 87^{\prime} 139$ & \\
\hline & Kahang Timur & & clay soil $^{1}$ & E. $103^{\circ} 28^{\prime} 559$ & 9 December 2015 \\
\hline \multirow[t]{2}{*}{ IdSPTK } & Indonesia Sako Pangean & Kuantan Singingi & Company Plantation \& & N. $00^{\circ} 20^{\prime} 314$ & \\
\hline & Taluk Kuantan & & sand Soil ${ }^{2}$ & E. $101^{\circ} 35^{\prime} 089$ & 7 March 2015 \\
\hline \multirow[t]{2}{*}{ MyLSK1 } & Malaysia, Ladang & Pahang & Company plantation \& & N. 02³6’194 & \\
\hline & Sg. Kemelai 1 & & sand soil ${ }^{2}$ & E. $103^{\circ} 30^{\prime} 399$ & 21 November 2015 \\
\hline \multirow[t]{2}{*}{ MyLSK2 } & Malaysia, Ladang & Pahang & Company plantation \& & N. $03^{\circ} 36^{\prime} 161$ & \\
\hline & Sg. Kemelai 2 & & sand soil ${ }^{2}$ & E. $103^{\circ} 30^{\prime} 277$ & 10 December 2015 \\
\hline \multirow[t]{2}{*}{ IdSgPK } & Indonesia Sungai & Kampar & Small plantation \& & N. $00^{\circ} 15^{\prime} 559$ & \\
\hline & Pagar Kampar & & peat soil ${ }^{3}$ & E. $101^{\circ} 24^{\prime} 623$ & 11 March 2015 \\
\hline \multirow[t]{2}{*}{ IdFRGB } & Indonesia First Resources & Bengkalis & Company plantation \& & N. $01^{\circ} 20^{\prime} 968$ & \\
\hline & Group Bengkalis & & peat soil ${ }^{3}$ & E. $102^{\circ} 01^{\prime} 441$ & 30 March 2015 \\
\hline \multirow[t]{2}{*}{ IdCPSK } & Indonesia Central Plantation & Kampar & Company plantation \& & N. $00^{\circ} 15^{\prime} 379$ & \\
\hline & Services Kampar & & peat soil ${ }^{3}$ & E. $101^{\circ} 35^{\prime} 979$ & 9 March 2015 \\
\hline
\end{tabular}

Notes: GPS - Global Positioning System. Soil ${ }^{\mathrm{n}}$ is mean of type soil on Dendogram two-way cluster and non-multidimensional scaling (NMDS) analysis.

groups were able to be distinguished based on the type of soil, namely, Group A (clay), Group B (sand and peat), Group C (clay), Group D (sand) and Group E (peat) (Figure 1).

The two-dimensional ordination (NMDS) described was summarised, $\mathrm{P}=0.0784$, the final stress $=1.74564$, final instability $=0.00000$, the coefficient to determine the distance between the ordination and the original distance in $n$-dimensional space $r^{2}$ $=0.838$ (Figure 2).

Three different types of soil, i.e. clay soil, sand and peat were able to be separated differently from one another. No overlaps on species composition between locations were observed.

Peat soil (IdCPSK, IdFRGB, IdSgPK) with sand soil (MyLSK1, MyLSK2, IdSPTK) showed clear separation on Axis 1, while clear separation was observed between peat soil (IdSgPK, IdFRGB, IdCPSK) with sand soil (IdSPTK, MyLSK1, MyLSK2) and clay soil (IdBCB, MyFKT, MyFNT) on Axis 2 (Figure 2).

Based on Chi-square, there was a significant difference $\left(\chi^{2}=618\right.$ 886, $\left.\mathrm{df}=328, \mathrm{p}<0.005\right)$ between soil types and termite species composition that were found in the oil palm plantations in Indonesia and Malaysia.

Groups I, III and VI have the most unique species because they are able to adapt to various soil types (clay, sand and peat) (b, c, d and e). The three groups comprised of the following termite species: (1) GI: Coptotermes curvignathus, C. kalshoveni, C. sepangensis, Nasutitermes havilandi, Microcerotermes dubius, Schedorhinotermes medioobscurus, S. malaccensis, (2) GIII; Parrhinotermes aequalis, Pericapritermes latignathus, P. butenzorgi, Nasutitermes roboratus, Schedorhinotermes brevialatus,
Nasutitermes proatripennis, N. longinasoides, Globitermes globosus, Odontotermes sp. B, and (3) GVI: Termes rostratus, Pericapritermes mohri and Macrotermes malaccensis. Most species from these groups are wood feeders, slightly organic, fungus and intermediate feeders. They are able to make their nests in various habitat types, i.e. wood nester, slightly arboreal nester, hypogeal, epigeal and soil nester (Figure 1).

Groups II and V have species that are able to adapt in peat soil (b, e). These two groups comprised of the following termite species: (1) GII: Parrhinotermes pygmaeus, Microcerotermes havilandi, Nasutitermes neopravus, and (2) GV: Prohamitermes mirabilis, Procapritermes sp. $G$ and Macrotermes gilvus. Many species from group II and V are wood feeders, slightly intermediate and intermediate or fungus feeders. Species from groups II and V groups are nest arboreal, slightly wood and epigeal nester (Figure 1).

Groups IV and IX have species that are able to adapt in sand soil $(b, d)$. These two groups comprised of the following termite species: (1) GIV: Schedorhinotermes javanicus, Microtermes pakistanicus, Bulbitermes neopasullis, B. contrictoides and (2) GIX: Procapritermes sp. A, Macrotermes cabonarius, M. sp. B, Odontotermes sp. G, Leocopritermes leucops, Nasutitermes matangensis. Many species from groups IV and IX are wood feeders, and slightly organic feeders, intermediate or fungus feeders and soil or fungus feeders. Groups IV and IX make their nest in epigeal and arboreal, slightly soil and wood nester (Figure 1).

Groups VII and VIII have termite species that are able to adapt in clay soil (c). These two groups 
TABLE 2. LIST OF TERMITES ACROSS OIL PALM AGROECOSYSTEM REGIONS IN RIAU (Indonesia) AND JOHOR (Peninsular Malaysia)

\begin{tabular}{|c|c|c|c|c|c|c|}
\hline Taxa & Abbreviation & $\begin{array}{c}\text { Functional } \\
\text { group }^{\not}\end{array}$ & $\begin{array}{l}\text { Feeding } \\
\text { group }^{+}\end{array}$ & $\begin{array}{c}\text { Nesting } \\
\text { group }^{\ddagger}\end{array}$ & Hits $^{\S}$ & Percentages \\
\hline \multicolumn{7}{|l|}{ RHINOTERMITIDAE } \\
\hline \multicolumn{7}{|l|}{ Coptotermitinae } \\
\hline Coptotermes curvignathus & COPcurv & I & $w$ & $\mathrm{w}$ & 4 & 2.33 \\
\hline Coptotermes kalshoveni & COPkals & I & $w$ & $\mathrm{w}$ & 5 & 2.91 \\
\hline Coptotermes sepangensis & COPsepa & $\mathrm{I}$ & $w$ & $\mathrm{~W}$ & 5 & 2.91 \\
\hline \multicolumn{7}{|l|}{ Rhinotermitinae } \\
\hline Parrhinotermes aequalis & PARaeq & $\mathrm{I}$ & $w$ & $\mathrm{w}$ & 4 & 2.33 \\
\hline Parrhinotermes pygmaeus & PARpygm & I & $w$ & $\mathrm{w}$ & 3 & 1.75 \\
\hline Schedorhinotermes brevialatus & SCHbrev & I & $w$ & w & 6 & 3.49 \\
\hline Schedorhinotermes javanicus & SCHjava & $\mathrm{I}$ & $w$ & $\mathrm{~W}$ & 1 & 0.58 \\
\hline Schedorhinotermes medioobscurus & SCHmedi & $\mathrm{I}$ & $w$ & $\mathrm{w}$ & 10 & 5.81 \\
\hline Schedorhinotermes malaccensis & SCHmala & $\mathrm{I}$ & $w$ & $\mathrm{~W}$ & 8 & 4.65 \\
\hline \multicolumn{7}{|l|}{ TERMITIDAE } \\
\hline \multicolumn{7}{|l|}{ Termitinae } \\
\hline Prohamitermes mirabilis & PHTmira & II & $w$ & $\mathrm{a}$ & 1 & 0.58 \\
\hline Globitermes globosus & GLOglo & II & $w$ & $\mathrm{i}$ & 32 & 18.61 \\
\hline Microcerotermes dubius & MCCdubi & II & $w$ & $\mathrm{a} / \mathrm{e}$ & 3 & 1.75 \\
\hline Microcerotermes havilandi & MCChavi & II & $w$ & $\mathrm{a} / \mathrm{e}$ & 2 & 1.16 \\
\hline Termes rostratus & TERrost & III & $i$ & $\mathrm{i}$ & 11 & 6.40 \\
\hline Procapritermes setiger & PROset & III & $i$ & $\mathrm{~h}$ & 1 & 0.58 \\
\hline Procapritermes sp. A & PROspA & III & $i$ & $\mathrm{~h}$ & 1 & 0.58 \\
\hline Procapritermes sp. G & PROspG & III & $i$ & $\mathrm{~h}$ & 2 & 1.16 \\
\hline Pericapritermes latignathus & PERlati & III & $o$ & $\mathrm{~h}$ & 3 & 1.75 \\
\hline Pericapritermes buteinzorgi & PERbtnz & III & $o$ & $\mathrm{~h}$ & 3 & 1.75 \\
\hline Pericapritermes mohri & PERmohr & III & $o$ & $\mathrm{~h}$ & 7 & 4.07 \\
\hline \multicolumn{7}{|l|}{ Macrotermitinae } \\
\hline Macrotermes cabonarius & MACcar & IIe & $w / l$ & $\mathrm{e}$ & 1 & 0.58 \\
\hline Macrotermes ahmadi & MACahm & IIe & $w / l$ & $\mathrm{e}$ & 2 & 1.16 \\
\hline Macrotermes gilvus & MACgilv & IIe & $w / l$ & $\mathrm{e}$ & 1 & 0.58 \\
\hline Macrotermes malacensis & MACmala & IIe & $w / l$ & $\mathrm{e}$ & 4 & 2.33 \\
\hline Macrotermes sp. B & MACspB & IIe & $w / l$ & $\mathrm{e}$ & 1 & 0.58 \\
\hline Odontotermes sp. B & ODOspB & II & $f$ & $\mathrm{~s}$ & 2 & 1.16 \\
\hline Odontotermes sp. C & ODOspC & II & $f$ & $\mathrm{~s}$ & 1 & 0.58 \\
\hline Odontotermes sp. D & ODOspD & II & $f$ & $\mathrm{~s}$ & 1 & 0.58 \\
\hline Odontotermes sp. E & ODOspE & II & $f$ & $\mathrm{~s}$ & 2 & 1.16 \\
\hline Odontotermes sp. G & ODOspG & II & $f$ & $\mathrm{~s}$ & 1 & 0.58 \\
\hline Microtermes pakistanicus & MICpaki & II & $w(f)$ & $\mathrm{w}$ & 1 & 0.58 \\
\hline \multicolumn{7}{|l|}{ Nasutitermitinae } \\
\hline Nasutitermes havilandi & NAShavi & II & $w$ & $\mathrm{a}$ & 6 & 3.49 \\
\hline Nasutitermes matangensis & NASmata & II & $w$ & $\mathrm{a}$ & 7 & 4.07 \\
\hline Nasutitermes neopravus & NASneop & II & $w$ & $\mathrm{a}$ & 2 & 1.16 \\
\hline Nasutitermes proatripennis & NASprtp & II & $w$ & $\mathrm{a}$ & 15 & 8.72 \\
\hline Nasutitermes longinasoides & NASlnds & II & $w$ & $\mathrm{a} / \mathrm{w}$ & 2 & 1.16 \\
\hline Nasutitermes roboratus & NASrobo & II & $w$ & a & 1 & 0.58 \\
\hline Bulbitermes constrictiformis & BULcttf & II & $w$ & $\mathrm{a}$ & 3 & 1.75 \\
\hline Bulbitermes constrictoides & BULcttd & II & $w$ & $\mathrm{a}$ & 5 & 2.91 \\
\hline Bulbitermes neopasullis & BULnpsl & II & $w$ & $\mathrm{a}$ & 1 & 0.58 \\
\hline Leocopritermes leucops ${ }^{N R}$ & LEUleu & III & $o$ & $\mathrm{~s}$ & 1 & 0.58 \\
\hline Total & & & & & 172 & $100 \%$ \\
\hline
\end{tabular}

Notes: ${ }^{x}$ The functional groups are (I) Group I (wood-feeder); (II) Group II (partially decayed wood feeder) [II(e)]; Group II(e) (micro epiphyte feeder) and (III) Group III (soil-interface and humus feeder).

${ }^{+}$The feeding groups are wood feeder $(w)$; litter feeder $(l)$; fungus grower $(f)$; soil-wood or intermediate feeder $(i)$; and organic soil feeder $(o)$

†The nesting groups are wood and tree nester (w); hypogeal nester (h); i.e. nests below ground surface; epygeal nester (e); i.e. nests with some part protruding above the ground; arboreal nester (a); i.e. nests totally above ground; and inquilines nester (i); i.e. sharing the nests built by another species of termite.

shits: number of encounter (surrogate to relative abundance/population).

${ }^{\mathrm{NR}} \mathrm{New}$ record species for oil palm in Peninsular Malaysia.

Source: Donovan et al. (2001); Gathorne-Hardy et al. (2002), 2006; Jones and Prasetyo (2002); Luke et al. (2014). 


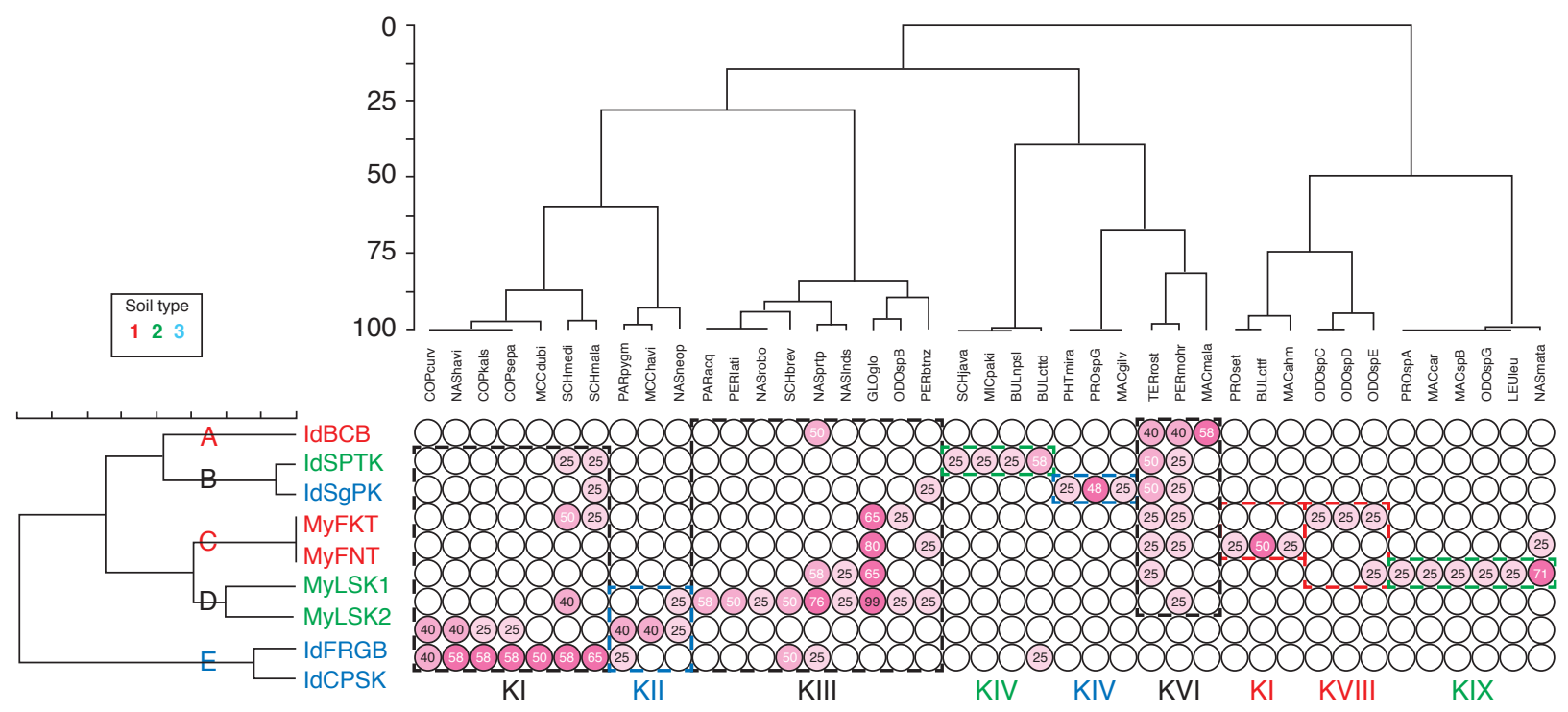

Figure 1. Dendogram of two-way cluster of termite species based on present matrix data generated by PC-Ord 6 and analysis of distance measured by Sorensen.

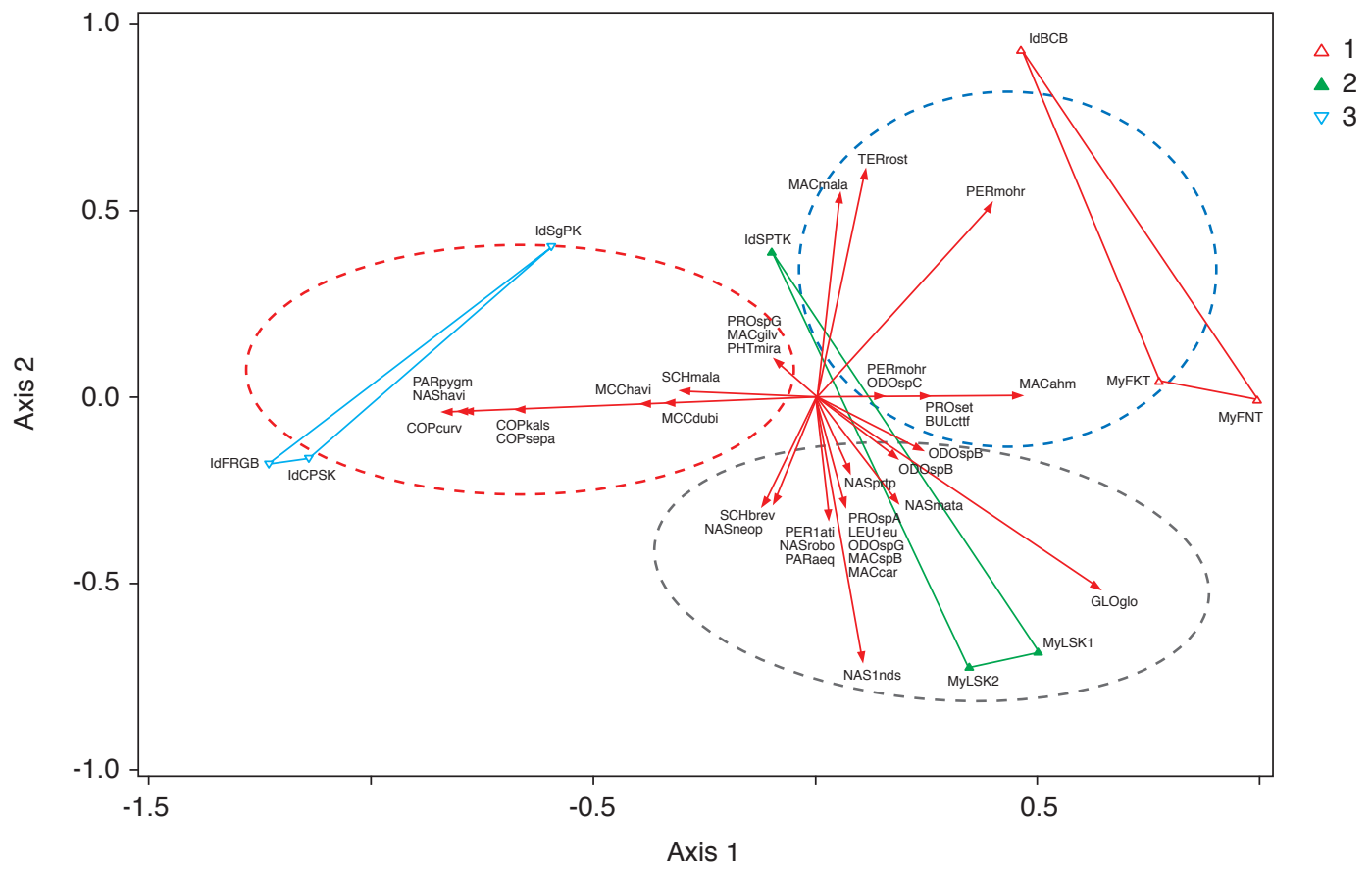

Figure 2. Two-dimensional ordination of nine transects based on a non-metric multidimensional scaling (NMDS) analysis generated by PC-Ord 6.

comprised of the following termite species: (1) GVII: Procapritermes setiger, Bulbitermes contrictiformis, Macrotermes ahmadi and (2) GVIII: Odontotermes sp. C, O. sp. D, O. sp. E. Most of the species in the latter groups are fungus feeder, slightly wood and intermediate feeders. Species in these groups also have many nests in soil, slightly hypogeal, arboreal and epigeal nester (Figure 1).

From the composition of termites, we also provided a list of termites with their association on soil type. Results show that different types of soil created different community of termites. Table 3 shows a list of termites and their preferences associated with soil types, exclusive or nonexclusively.

\section{DISCUSSION}

The species diversity and composition of termites in oil palm plantations in Malaysia and Indonesia were as expected. From previous studies in oil palm plantations in Malaysia and Indonesia, species 
TABLE 3. LIST OF TERMITES ASSOCIATED WITH THREE TYPES OF SOIL ON OIL PALM PLANTATIONS AND POTENTIAL PESTS

\begin{tabular}{|c|c|c|}
\hline Peat soil & Sand soil & Clay soil \\
\hline Coptotermes curvignathus ${ }^{P P}$ & Bulbitermes constrictitoides & Bulbitermes constrictiformis \\
\hline C. kalshoveni & B. neopossulis & Globitermes globosus ${ }^{P P}$ \\
\hline C. sepangensis ${ }^{P P}$ & Globitermes globosus ${ }^{P P}$ & Macrotermes ahmadi \\
\hline Macrotermes gilvus ${ }^{P P}$ & Leocopritermes leucops & Macrotermes malaccensis \\
\hline Microcerotermes havilandi & Macrotermes carbonarius & Nasutitermes proatripennis \\
\hline M. dubius & M. malaccensis & Odontotermes sp. $\mathrm{B}^{\mathrm{PP}}$ \\
\hline Nasutitermes neopravus & M. sp. B & O.sp. $C^{\mathrm{PP}}$ \\
\hline N. havilandi* & Microtermes pakistanicus ${ }^{P P}$ & O. sp. $\mathrm{D}^{\mathrm{PP}}$ \\
\hline N. proatripennis & Nasutitermes longinasoides & O. sp. $E^{\mathrm{PP}}$ \\
\hline Parrhinotermes pygmaeus & N. matangensis & Pericapritermes buteinzorgi \\
\hline Pericapritermes buteinzorgi & N. proatripennis & P. mohri \\
\hline P. mohri & N. roboratus & Procapritermes setiger \\
\hline Procapritermes sp. G & Odontotermes sp. $\mathrm{B}^{\mathrm{PP}}$ & Schedorhinotermes medioobscurus ${ }^{P P}$ \\
\hline Prohamitermes mirabilis & O. sp. $\mathrm{G}^{\mathrm{PP}}$ & S. malaccensis ${ }^{P P}$ \\
\hline Schedorhinotermes medioobscurus ${ }^{P P}$ & Parrhinotermes aequalis & Termes rostratus \\
\hline S. malaccensis ${ }^{P P}$ & Pericapritermes buteinzorgi & - \\
\hline Termes rostratus & P. latignathus & - \\
\hline- & P. mohri & - \\
\hline- & Procapritermes sp. A & - \\
\hline- & Schedorhinotermes brevialatus ${ }^{P P}$ & - \\
\hline- & S. javanicus ${ }^{P P}$ & - \\
\hline- & S. medioobscurus ${ }^{P P}$ & - \\
\hline- & S. malaccensis $^{P P}$ & - \\
\hline- & Termes rostratus & - \\
\hline
\end{tabular}

Note: ${ }^{*} \mathrm{PP}$ - potential pest found in oil palm plantation.

from the family Termitidae were frequently been encountered in high abundance $(>60 \%$ ) (Faszly et al., 2011; Kon et al., 2012; Saputra et al., 2016a; Saputra, 2017). The most frequently encountered groups were from the subfamily Termitinae (38.39\% from 66 populations). This group can be found throughout the tropics and have high species richness in the sundanic region (Eggleton et al., 1997; Eggleton, 2000). In terms of species, Globitermes globosus (18.61\% from 32 populations), Nasutitermes proatripennis (8.72\% from 15 populations) and Termes rostratus $(6.40 \%$ from 11 populations) contributed to the most number of individuals.

Globitermes globosus (wood feeder) is commonly found in oil palm plantations and in lowland dipterocarp forest (Tho, 1992). Nasutitermes proatripennis, a wood feeder(decomposer)is normally found in undisturbed forest (Syaukani, 2004) while Termes rostratus, a soil-wood or intermediate feeder inhabited lowland areas to hill dipterocarp forest (Tho, 1992). On the contrary, in this study, Leucopitermes leucops (Termitidae: Nasutitermitinae) was considered as a newly recorded species in oil palm plantations for Peninsular Malaysia. This species was encountered in at MyLSK1 (Malaysia, Sungai Kemelai Plantation, Pahang Foundation, Endau-Rompin, Pahang). Based on the geographical distribution, this species spreads along Sumatra,
Peninsular Malaysia, Java and Borneo (Syaukani, 2004).

There were only nine species from the family Rhinotermitidae that were managed to be recorded in this study. This includes subfamily Rhinotermitinae (18.61\% from 32 populations) and Coptotermitinae (8.15\% and 14 populations). Most species encountered from this family were from the genera Coptotermes, Parhinotermes and Schedorhinotermes. Species from these genera can easily be found in oil palm in Sarawak (Bong et al., 2012). They are known as pests, i.e. wood feeders (Cheng et al., 2008), especially Coptotermes curvignathus which gives the most threats in oil palm plantation (Khoo et al., 2001).

The presence of the fungus growing termites, Odontotermes spp. in oil palm plantations demonstrates the ability of this species to endure environmental changes as ecosystem engineers (Jouquet et al., 2004). On the contrary, species from the genus Coptotermes, Odontotermes, Microtermes, Macrotermes, Pseudacanthotermes and Ancistrotermes in these groups are known pests (Rouland-Lerevre, 2011). They are commonly found in oil palm plantations in this region. In Groups II and V, species such as Macrotermes gilvus plays an important role as decomposer in an ecosystem (Primanda et al., 2003). Species from Groups IV and 
IX have been indicated as those species affected with soil properties, every change on soil will affect them directly (Shelton et al., 2000). The termite species within these groups live as epigeal, hypogeal or arboreal, with their nests built up above or in the soil. Species from Groups IV, VII, VIII and IX which are soil feeders and fungus feeders can also be found. Species from this group could act as an indicator for non-disturb conditions, as the species are not able to withstand disturbance and any changes to the microenviromental would have affected them (Dibog et al., 1999; Eggleton et al., 1997).

Differences in the type of soil has a significant impact on the composition of the species of termites. Sand soil that are able to support the mounds built by termites have the highest number of species (24 species) and are mostly dominated by soil feeders (Table 3). Seventeen species of termites were encountered in peat soil (Table 3). This peat soil has termite species such as Coptotermes spp. and Schedorhinotermes spp. which are considered as pests. Previous studies have identified that termite species inhabiting this peat soil type are mostly wood feeders that are of great concern to farmers. The use of chemicals could eliminate their presence in a short time (Saputra, 2017). Prevention from termite damage with the use of various termite traps, use of chemical pesticides and using natural enemies such as fungi (Trichoderma spp.) are being done to reduce the crop damage (Faszly, 2008). Still, the results from these efforts are unsatisfactory. Moreover, the water level (low or high) of the peat soil also influences the vertical distribution of termite species, e.g. constructing nest up on trees.

In addition, only 15 species of termites were found in clay soil (Table 3). This clay soil is likely to be dominated by species such as Macrotermes spp, which favour building high mounds that are able to withstand predators attack. Clay soil have solid materials that termites used to protect and control their colonies from predators (Kon et al., 2012; Korb, 2011).

The most common termite pest occurrence is the Coptotermes sp. which outrageously infested plantations and many economic losses had been recorded for decades. They eat meristem apical on growth point of the plants or bring diseases which are directly transferred to plants. Kalshoven (1963) has recorded that termites have done very serious infestation on palm trees. In Indonesia, Sudartho and de Chenon (1990) had published that C. curvignathus infested outrageously on oil palm namely PT Perkebunan IV and Torgamba. This species can attack oil palm starting from the root until to the tip of the plant. According of Sajap (1999), C. curvignathus had been infesting not only oil palm plantation but also other plantations, i.e. mango, durian, papaya and rubber plantations in Malaysia. Apart from that, these termite species have been recorded as pest in several publications namely: Schedorhinotermes sp., Macrotermes gilvus, Microtermes sp., Globitermes sp. and Odontotermes sp. (Nandika et al., 2003; Cheng et al., 2008; Faszly, 2008; Faszly et al., 2011; Neoh et al., 2011; Bong et al., 2012; Saputra et al., 2016a, b; 2017; Saputra, 2017) (Table 3).

We agree with Cheng et al. (2008) who stated in their studies that termite species such as Schedorhinotermes spp. Pericapritermes spp., $H$. atripennis, $C$. sepangensis and lastly $P$. aequalis are scavengers and commonly found in oil palm plantations. However, they induce no economical damage to oil palm and probably may have positively improved soil condition as ecosystem engineer.

Pests on plantation or agroecosystem have different controlling systems compared to urban pests. This had become more complex as pesticides also have impact on non-pest insects. Therefore, we need to check carefully about the infestation status going on in that plantation to understand what kinds of termite infesting, termite species, symptoms, and damage they cause on that plantation. Also, we need to deliberate economic loss with calculation of yield loss and how many of dead plants because of the infestation. With the right calculation of loss, we can provide the right technique and economical termite pest control approaches (Nandika et al., 2003).

Different communities of termites are found in different soil types. The variation occurs because there are differences in the termite's ability to adapt to various soil types. In this study, the same termite species were also found at different soil types (Figure $1)$. There are several chemical and non-chemical methods that can be adopted to control them.

For clay and sand soil areas, we can apply some strategic control approach of Integrated Pest Management (IPM) with the usage of chemical. Baits and liquid pesticides can be utilised in this approach. Pesticide-treated rubber wood chuck can be used as bait. This toxic bait contains hexaflumuron and noviflumuron in liquid form. The other form of toxic bait is in dust form, i.e. arsenic trioxide, triflumuron and phenyl pyrazole. The usage of rubber wood treated with low concentration of chemicals as mentioned will attract termites to feed on them. Once exposed, the contaminated termites re-enter or forage back to the colony to spread the toxicant by feeding each other (Trophalaxis) and grooming behaviour. Liquid pesticides can also be injected directly into the termite mound, mud tube or by spraying onto infested palms (Nandika et al., 2003). Either using liquid or baiting, principally, we should know the right dosage to be applied on soil or oil palm that have been infested. With the right portion, we can kill the termite effectively and not to become resistant to the chemical. Chemical control is more applicable because in some situation, termite nest or path is easily found in clay and sand soil, but the 
application of non-chemical controlling methods is still possible.

For peat area, Cheng et al. (2008) suggested that chemical approach as commonly practiced may be unnecessary for C. curvignathus. But, this approach is less likely able to kill them. We can apply other strategic control approach of IPM with the use of non-chemical control. This involves the use of biological control such as entomopathogenic nematode, fungus, bacteria and virus. For instance, the nematode entomopathogens, e.g. Steinernema sp. and Heterorhabditis indica have been used to control termite species. The nematodes are transferred into termite's body, end up infesting the whole body and slowly killing the termite. However, these nematodes are only able to infest the termite colonies that are exposed to watery condition. Termites also have some ability to isolate infested weak termites from their colony (Arinana, 2002; Nandika et al., 2003; Lenz, 2005). Other biological control agents, such as fungi (Metarhizium anisopliae) have been used as an alternative approach to control termite pest (Chouvenc et al., 2008; Wright et al., 2005). Bacillus thuringiensis (Bt) is also commonly used in biological control as the bacterial pathogens can kill the insect. In generative stage, this Bt produces some toxin, known as endotoxin from insect's internal body parts. This toxin damages the intestinal wall and paralyzes the intestinal muscles of insect. The termite would die within a short period of time (Sudono et al., 2007). Next, Nuclear Polyhedrosis Viruses (NPV) also can act as a biological control agent. This virus can infect the intestine of termite directly with virion as matrix protein called Polyhedral Inclusion Bodies (PIB) (Fazairy and Hassan, 1988). This virus is suggested as a good candidate for biological control of termites because it has the capability to complete its life cycle and spread, before the host dies (Sahayaraj, 2017). However, Indrayani et al. (2012) identified a new bio-termiticide which uses liquid smoke from empty fruit bunch waste, which can be provide another alternative in controlling termite on peat. This strategy needs to be developed for sustainable termite management on peat.

We need to focus in killing not only for certain termite castes (such as certain soldiers or workers) but we need to kill the entire colony. If succeeded, then it can be considered as a success for controlling termites in the oil palm plantation.

\section{CONCLUSION}

The diversity and abundance of termites from different soil types (i.e. clay, sand and peat) in oil palms were assessed and evaluated. Termite communities are different between soil types in oil palm plantation. Thus, various preventive approaches should be taken into consideration to reduce termite entry into plantation as well as to overcome the pest species from dispersing widely around the plantations. Besides, to control the infestation, the palm itself has to be resistant to termite attack. IPM which integrates various control practices is important to reduce termite infestation in oil palm plantations.

\section{ACKNOWLEDGEMENT}

Thanks are dedicated to Central Plantation Services (PT Central Alam Resources Lestari), First Resources Groups (PT Surya Dumai Agrindo) and small plantations around Sungai Pagar, Kampar, Batang Cenaku, Belilas, Indragiri Hulu and Sako, Pangean, Taluk Kuantan, Riau, Indonesia. Yayasan Pahang Plantation Holding Sdn Bhd (Endau Rompin Plantation and Sungai Kemelai Plantation), Pahang, Malaysia; Felda Nitar Timur, Felda Kahang Timur and small plantation around Bukit Pasir, Muar, Johor, Malaysia for approving this study and for permission to conduct research at their plantation areas. We appreciate the cooperation and assistance rendered to members of the Terrestrial Ecology Laboratory in carrying out this research from 2015 to 2016. This research is partly funded by the Ministry of Higher Education's fundamental research grant scheme (FRGS/2/2014/STWN03/UKM/03/1) and the Sime Darby Chair for Climate Change Internal Seed Fund to the Oil Palm Ecological Restoration and Agroecosystem Services Inventory (OPERASI) (ZF-2013-011) Group.

\section{REFERENCES}

ARINANA (2002). Keefektifan Nematoda Entomopatogen Steinernema sp. dan Heterorhanditis indica sebagai Agen Hayati Pengendali Rayap Tanah Coptotermes curvignathus Holmgren (Isoptera: Rhinotermitidae). M. Sc. thesis, Institut Pertanian, Bogor, Indonesia.

AZAM, I; SARWAR, M K; IQBAL, W; IRAM, N and AZAM, F (2015). Studies on population density and diversity of termites of district Gujranwala, Pakistan. J. Entomol. Zool. Stud. Vol. 3(6): 160-163.

BONG, J C F; KING, P J H; ONG, K H and MAHADI, N M (2012). Termite assemblages in oil palm plantation in Sarawak, Malaysia. J. Entomol. Vol. 9(2): 68-78.

CHENG, S; KIRTON, L G and GURMIT, S (2008). Termite attack on oil palm grown on peat soil: Identification of pest species and factors contributing to the problem. The Planter. Vol. 84(991): 200-210. 
CHOUVENC, T; SU, NAN-YAO and ELLIOTT, M L (2008). Interaction between the subterranean termite Reticulitermes flacipes (Isoptera: Rhinotermitidae) and the Entomopathogenic fugus Metarhizium anisopliae in foraging arenas. J. Econ Entomol. Vol. 101(3): 885-893.

DAVIES, R G; HERNANDEZ, L M; EGGLETON, P; DIDHAM, R K; FAGAN, L L and WINCHERSTER, $N$ (2003). Environmental and spatial influences upon species composition of termite assemblages across neotropical forest islands. J. Trop Ecol. Vol. 19: 509-524.

DIBOG, L; EGGLETON, P; NORGROVE, L; BIGNELL, D E and HAUSER, S (1999). Impacts of canopy cover on soil termite assemblages in an agrisilvicultural systems in Southern Cameroon. Bull. Entomol. Res. Vol. 89: 125-132.

DIKA, TUBAGUS MUHAMAD (2010). Karakterisasi Fisik Gambut di Riau Pada Tiga Ekosistem (marine, payau, dan air tawar). Undergraduate thesis, Institut Pertanian Bogor, Indonesia.

DIREKTORAT JENDERAL PERKEBUNAN (2016). Statistik Perkebunan Indonesia Komiditas Kelapa Sawit 2015-2017. Sekretariat Direktorat Jenderal Perkebunan Kementerian Pertanian, Jakarta, Indonesia.

DUC, N M; LO, B T; ANH, D T N; MY, N T; QUANG, N V and HANH, T V (2016). Data on species composition of termites (Insecta: Isoptera) in Bac Huong Hoa Nature Reserve, Quang Tri Province. VNU J. Science: Natural Science and Technology Vol. 32(1): 18-25.

EGGLETON, P (2000). Global patterns of termite diversity. Termites: Evolution, Sociality, Symbioses, Ecology (Abe, T; Bignell, D E and Hagashi, H eds.). Kluwer Academic Publisher, The Netherlands. p. 25-51.

EGGLETON, P; BIGNELL, D E; SANDS, W A; MAWDSLEY, N A; LAWTON, J H; WOOD, T G and BIGNELL, N C (1996). The diversity, abundance and biomass of termites under differing levels of disturbance in the Mbalmayo Forest Reserve, Southern Cameroon. Philos. Trans. Royal Soc. B. Vol. 351: 51-68.

EGGLETON, P; HOMATHEVI, R; JEEVA, D; JONES, D T; DAVIES, R G and MARYATI, M (1997). The species richness and composition of termites (Isoptera) in primary and regenerating lowland dipterocarp forest in Sabah, East Malaysia. Ecotropica Vol. 3: 119-128.
FASZLY, R (2008). Community Ecology of Termite and Pest Incidences in Converted Oil Palm on Peat in Malaysia. Ph.D thesis, Universiti Kebangsaan Malaysia, Malaysia.

FASZLY, R; MUHAMMAD-FARIS, M E; AZIZILALIMIN, M M; SHAFURAA, O; ANNIE-NUNIS, A B; NORMAN, K; IDRIS, A B and SAJAP, A S (2011). Termites of oil palm on peat soil: A 10-year collection from Endau Rompin. Serangga Vol. 16(2): 37-56.

FAZAIRY, A A A and HASSAN, F A (1988). Infection of termites by Spodoptera littoralis Nuclear Polyhendrosis Virus. Insect. Sci. Applic. Vol. 9(1): 3739.

FOSTER, W A; SNADDON, J L; TURNER, E C; FAYLE, T M; COCKERILL, T D; ELLWOOD, M F; BROAD, G R; CHUNG, A Y; EGGLETON, P; KHEN, C V and YUSAH, K M (2011). Establishing the evidence base for maintaining biodiversity and ecosystem function in the oil palm landscapes of South East Asia. Phil. Trans. R. Soc. B. Vol. 366: 32773291.

GUNARSO, P; HARTOYO, M E; FAHMUDDIN, A and KILLEEN, T J (2013). Oil palm and land use change in Indonesia, Malaysia and Papua New Guinea. Reports from the Technical Panels of the $2^{\text {nd }}$ Greenhouse Gas Working Group of the Roundtable on Sustainable Palm Oil (RSPO).

HARJOWIGENO, S (1989). Sifat-sifat dan potensi tanah gambut Sumatra untuk pengembangan pertanian. Prosiding Seminar Tanah Gambut untuk Perluasan Pertanian (Hakim, N M Y; Nyakpa, A M; Lubis, S E, Nugroho, M A; Diha; Go, Ban Hong and Bailey, H H eds.). Medan, Indonesia.

INDRAYANI, Y; NURHAIDA and ORAMAHI, H A (2012). Pengendalian serangan rayap pada tanaman kelapa sawit. Prosiding Seminar Nasional Masyarakat Peneliti Kayu Indonesia (MAPEKI) XIV. Yogyakarta, Indonesia.

ISLAMI, T and UTOMO, W H (1995). Hubungan Tanah Air dan Tanaman. IKIP Semarang Press.

JONES, D T and EGGLETON, P (2000). Sampling termite assemblages in tropical forests: Testing a rapid biodiversity assessment protocol. J. Appl. Ecol. Vol. 37: 191-203.

JOUQUET, P; BOULAIN, N; GIGNOUX, J and LEPAGE, M (2004). Association between subterranean termites and grasses in a West African Savanna: Spatial pattern analysis shows a significant role for Odontotermes nr pauperans. Appl. Soil Ecol. Vol. 27: 99-107. 
KALSHOVEN, LGE (1963). Coptotermes curvignathus causing the death of trees in Indonesia and Malaya. Ent. Ber Thehaque. Vol. 23: 90-100.

KAMALRUDIN, M S and ABDULLAH, R (2014). Malaysian palm oil - Moving ahead to sustainable production growth. Oil Palm Industry Economic J. Vol. 14(1): 24-33.

KAMBHAMPATI, S and EGGLETON, P (2000). Phylogenetics and taxonomy. Termites: Evolution, Sociality, Symbioses, Ecology (Abe, T, Bignell, D E, Higashi, M eds.). Dordrecht: Kluwer Academic Publishing, The Netherlands. p. 1-23.

KHOO, K C; LIM, K M; SINGH, G and SHARMA, $M$ (2001). A comparative study of the species of termites and their distribution in the fields of oil palm growing on peat and mineral soils. Proc. of the $4^{\text {th }}$ Asia Pacific Conference of Entomology. Kuala Lumpur, Malaysia. p. 14-17.

KON, T W; CHOON-FAN, J B; JIE-HUNG, P and CHAN-TECK, S L (2012). Biodiversity of termite (Insecta: Isoptera) in tropical peat land cultivated with oil palms. Pak. J. Biol. Sci. Vol. 15(3): 108-120.

KORB, J (2007). Termites. Biol. Curr. Vol. 17(23): R995-R999.

KORB, K (2011). Termite mound architecture from function to construction. Biology of Termites: A Modern Synthesis (Bignell, D E et al. eds.). p. 349-373.

LAVELLE, P; DECAENS, T; AUBERT, M; BAROT, S; BLOUIN, M; BUREAU, F; MARGERIE, P; MORA, $P$ and ROSSI, J P (2006). Soil invertebrates and ecosystem services. Eur. J. Soil Biol.: S3-S15.

LENZ, M (2005). Biological control in termite management: The potential of nematodes and fungal pathogens. Proc. of the Fifth International Conference on Urban Pests. Singapore.

MCCUNE, B; GRACE, J B and URBAN, D L (2002). Analysis of Ecological Communities. MjM Software Design. p. 304.

NANDIKA, D; RISMAYADI, Y; DIBA, F and JOKO, H (2003). Rayap Biologi dan Pengendaliannya. Muhammadiyah University Press, Surakarta, Indonesia.

NEOH, K B; JALALUDIN, N A and LEE, C Y (2011). Elimination of field colonies of a moundbuilding termite Globitermes sulphures (Isoptera:
Termitidae) by bistrifluror. J. Econ. Entomol. Vol. 104(2): 607-613.

POOVOLI, A and RAJMOHANA, K (2016). Feeding group diversity of termites (Isoptera: Insecta) in Kerala. J. Entomol. Zool. Stud. Vol. 4(4): 114-116.

PRIMANDA, A; ISCHAK, T $\mathrm{M}$ and BASUKRIADI, A (2003). Termite species richness on the campus of Universitas Indonesia, Depok. Makara Sains Vol. 7(1): 9-14.

ROULAND- LEFEVRE, C (2011). Termite as pests of agriculture. Biology of Termites: A Modern Synthesis (Bignell, D E et al. eds.). p. 499-517.

SAHAYARAJ, K (2017) Bio-intensive Integrated Management of Termites. Termites and Sustainable Management (Khan, M A and Ahmad, W eds.). Vol. 2. p. 147.

SAJAP, A S (1999). Detection of foraging activity of Coptotermes curvignathus (Isoptera: Rhinotermitidae) in an Hevea brasiliensis plantation in Malaysia. Sociobiology Vol. 33: 137-143.

SAPUTRA, A (2017). Diversity and Distribution of Termites (Blattodea: Termitoidea) in Oil Palm Ecosystem at Riau (Indonesia), and Johor-Pahang (Peninsular Malaysia) Based on Different Types of Soil and Microhabitat. M.Sc. thesis, Universiti Kebangsaan Malaysia, Malaysia.

SAPUTRA, A; HALIM, M; NUR- ATIQAH, J; IZFA, R H and FASZLY, R (2017). Effects of day time sampling on the activities of termites in oil palm plantation int Malaysia-Indonesia. Serangga Vol. 21(1): 23-28.

SAPUTRA, A; JALALUDIN, N A; HAZMI, I R and RAHIM, F (2016a). Termite assamblages from oil palm agroecosystems across Riau Province, Sumatra, Indonesia. AIP Conference Proceedings. Bangi, Malaysia.

SAPUTRA, A; NUR-ATIQAH J; IZFA, $\mathrm{R} \mathrm{H}$ and FASZLY, R (2016b). Composition of termites and distribution in oil palm agroecosystems in Peninsular Malaysia. Proc. of the $14^{\text {th }}$ Symposium of Malaysian Society of Applied Biology. Melaka, Malaysia.

SHELTON, T G; FOSHEE III, $W$ and APPEL, A G (2000). Drywood Termite Biology Identification and Control. Albana \& A\&M and Aubrun Universities.

SUDARTHO, P S and DECHENON, S R D (1990). Termite, A new problem on oil plantation in Indonesia. Seminar Nasional dan Diskusi Panel Perlindungan Tumbuhan Indonesia Barat. Medan, Indonesia. 
SUDONO, S; MARDJI, D and BOER, C (2007). Effectiveness of Bacillus thuringiensis Berl. and Beauveria bassiana Bass. on the death of some species of plant destroyer animals. Jurnal Kehutahan UNMUL. Vol 3(1): 77-86.

SYAUKANI (2004). A Guide to the Nasustermites (Nasutitermitinae, Termitidae) of Kerinci Seblat National Park, Sumatra. Nagao Natural Environment Foundation. Tokyo, Japan.

THAPA, R S (1981). Termites of Sabah (East Malaysia). Sabah Forest Record. Sabah, Malaysia. p. 12.
THO, Y P (1992). Termites of Peninsular Malaysia. Forest Reserach Institute Malaysia, Kuala Lumpur, Malaysia.

WENDY, Y W and WILLIAM, A F (2015). The effects of forest conversion to oil palm on ground-foraging ant communities depend on beta diversity and sampling grain. Ecol. Evol. Vol. 5(15): 315.

WRIGHT, M S; RAINA, A K and LAX, A R (2005). A strain of the fungus Metarhizium anisopliae for controlling subterranean termites. J. Econ. Entomol. Vol. 98(5): 1451. 